\title{
Slaget om hiv er ikke over - sats lokalt ⿶ㅕ을
}

\author{
Talet på nye tilfelle av hivsmitte har globalt sett gått nedover sidan slutten av 1990-åra. Slaget er likevel langt \\ frå over - aller minst i delar av Afrika der ekstremt tunge epidemiar berre er blitt litt mindre omfattande \\ og framleis har katastrofale sosiale og økonomiske innverknader. Ein avgjerande suksessfaktor frametter \\ er investering i lokal kompetanse.
}

Engelsk oversettelse av hele artikkelen på www.tidsskriftet.no

\section{Knut Fylkesnes}

knut.fylkesnes@cih.uib.no

Marte Jürgensen

Ingvild Fossgard Sandøy

Senter for internasjonal helse

Universitetet i Bergen

Utbreiinga av hiv var lenge kraftig overestimert grunna mangelfulle nasjonale epidemiologiske system. På grunnlag av betra datagrunnlag blei omfanget av pandemien justert kraftig ned i 2007. Estimert hivprevalens blei redusert med $33 \%$ globalt og med $36 \%$ for Afrika sør for Sahara (1). Betringa av nasjonale system i Afrika kom primært i form av investering i befolkningsstudiar som eit supplement til data frå kvinner som møtte til svangerskapskontroll ved utvalde klinikkar. Datagrunnlaget blei også betra i land der hivsmitte er konsentrert innan spesielle grupper. Trendar i hivprevalens over tid hos unge gir ein god peikepinn på trendar i insidens (nysmitte) i epidemiar som er generaliserte, og sikrare prevalensdata gir sikrare estimering av insidens.

Om lag 2,6 millionar menneske blei smitta med hiv på verdsbasis i 2009. Dette er nesten $20 \%$ færre enn i 2001 (etter justering av tidlegare overestimat). I 33 land er insidensen redusert med meir enn $25 \%$ sidan 2001, og 22 av desse landa ligg i Afrika sør for Sahara (1). I denne regionen lever $67 \%$ av alle hivsmitta, og det meste av smitten skjer seksuelt mellom menn og kvinner i den generelle befolkninga. Tyngdepunktet finn vi i ti land i det sørlege Afrika. Hivprevalensen i Vest- og Sentral-Afrika er til samanlikning låg, på berre $2 \%$ blant vaksne. Tidleg i epidemien dominerte det mindre infeksiøse hiv-2 i denne regionen, men seinare har også hiv-1 spreidd seg til Vest-Afrika utan at ein har fått ein like stor epidemi som i det austlege og sørlege Afrika. Utbreidd mannleg omskjering i Vest-Afrika har vore framlagt som ei viktig forklaring på dette (2). Trass $i$ nedgangen $i$ insidens har prevalensen i Afrika sør for Sahara gått opp grunna auka tilgang til behandling. I 2009 var det $37 \%$ av dei som fylde behandlingskriteria som fekk behandling, noko som er ei stor betring sidan 2002 då tilsvarande tal var $2 \%$ (1).

I andre regionar er epidemiane med få unntak konsentrerte blant særlege grupper i befolkninga, og i enkelte land er epidemiane i disse gruppene framleis veksande. Størst er auken i Aust-Europa og SentralAsia. I tidlegare sovjetstatar har ei rask stigning i injiserande narkotikabruk ført til ein stor auke i nysmitte innan denne gruppa. I Asia er epidemien stabil og konsentrert blant injiserande narkotikabrukarar, menn som har sex med menn og sexarbeidarar. Også i Sentral- og Sør-Amerika er førekomsten låg og stabil. Her er hiv konsentrert i nettverk av menn som har sex med menn og blant injiserande narkotikabrukarar. I Nord-Amerika og Vest-Europa er det urovekkjande teikn på aukande insidens blant menn som har sex med menn, assosiert med ein auke i seksuell risikoåtferd. I Midtausten og Nord-Afrika ser ein òg noko aukande insidens, men det manglar pålitelege data frå denne regionen. Førekomsten av hiv er låg her, med unntak av i Djibouti og Sør-Sudan, som har generaliserte epidemiar.

\section{Sosiale skilnader}

I siste oppdatering om hivtrendar rapporterte UNAIDS at hivinsidensen i Afrika sør for Sahara mest truleg nådde toppen midt på 1990-talet (1). Dette er ei «gjennomsnittsutsegn» som kan vere problematisk fordi den er med på å maskere stor geografisk variasjon. Dessutan er det store kontrastar mellom ulike sosiale grupper innanfor eit land. I tidleg fase av hivpandemien, før førebyggjande tiltak vart sett $\mathrm{i}$ gang, var

det den delen av befolkninga med høgast utdanning som viste seg å vere hardast ramma. Dette fekk alvorlege implikasjonar som følgje av særleg høg mortalitet blant profesjonsgrupper (legar, sjukepleiarar, lærarar) som allereie var ein særs knapp ressurs. Seinare har assosiasjonen mellom utdanningsnivå og hiv snudd, dvs. at når førebyggjande tiltak blei sette inn, var det dei høgast utdanna som responderte best $(3,4)$ (fig 1$)$. Generelt er fallet $\mathrm{i}$ hivinsidens assosiert med redusert risikoåtferd i form av meir konsekvent kondombruk og reduksjon i talet på partnarar (5). Likevel, etter ein lang heteroseksuell epidemi som truleg har vart i 40-50 år i ei rekke land (6), finn vi blant mange ektefellar og seksualpartnarar at den eine partnaren er hivnegativ og den andre hivpositiv. Dette gjeld rundt $10 \%$ av gifte par i det austlege Afrika (Kenya, Uganda og Tanzania), 15\% i Zambia, og $27 \%$ i Sør-Afrika(7, 8). På grunnlag av data frå Rwanda og Zambia er det blitt berekna at minst $60 \%$, og kanskje så mykje som $90 \%$, av all heteroseksuell nysmitte i desse landa skjer blant gifte eller sambuande par (9). Denne forma for smitte ser ut til å vere vanskeleg å redusere.

\section{Den globale responsen}

Global mobilisering av ressursar til hiv/ aids-tiltak var ingen suksess, korkje på 1980- eller på 1990-talet. Mobilisering i land der epidemiane var alvorlegast blei lenge hindra av ei utbredd oppfatning av at hiv/aids var ein amerikansk sjukdom som ramma homoseksuelle og stoffmisbrukarar (10). Responsen i Afrika kom derfor ikkje i gang før seint på 1980-talet då epidemiane i mange afrikanske land hadde rast i meir enn ti år. WHO etablerte det globale aidsprogrammet, Global Programme on AIDS

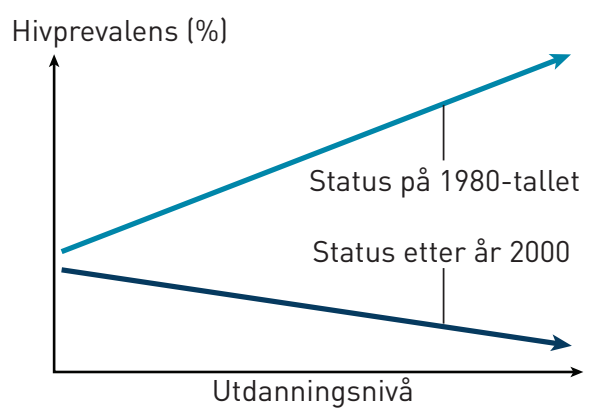

Figur 1 Endring over tid av fordelinga av hivsmitte (hos unge) etter utdanningsbakgrunn i Afrika sør for Sahara 
(GPA), med siktemål å vere døropnar for alle ressursar til nasjonale aidsprogram. Diverre blei programmet ingen suksess, mykje på grunn av indre motsetnader og manglande aksept frå viktige donorar for strategien som døropnar. I 1995 blei det lagt ned, og FN-systemet gjekk saman om å etablere UNAIDS med primæroppgåve som pådrivar og koordinator for ei multisektorsatsing. Organisasjonen skulle ikkje ha ansvar for finansiering av aidsprogram (10). UNAIDS tok derimot på seg ansvaret for epidemiologisk kartlegging. Suksessen til UNAIDS som pådrivar var lite å skryte av dei første fem åra, der ein ikkje makta å mobilisere nemneverdig med ressursar til hivprogram i låginntektsland. Vinden snudde først etter den første spesialsesjon på hiv/aids (UNGASS) i regi av FN i 2001 og med etableringa av «Det globale fondet for HIV/TB og malaria» i 2002. Perioden 2000-10 var glansperioden for globale hiv/ aids-initiativ med ein vekst $i$ årleg budsjettramme frå 1 milliard til 16 milliardar amerikanske dollar. Med andre ord er det berre det siste tiåret ein kan seie at verdssamfunnet verkeleg har lukkast i å mobilisere ressursar til hiv/aids-relatert arbeid i låginntektsland. UNAIDS har lause system for koordinering, og dette har påverka prioriteringane, og i stor grad ser vi diverre altfor tydeleg at regelen som rår er «Those who have the gold, make the rules»».

\section{Kunnskap om lokal kontekst}

Skilnadene på hivepidemiane mellom og innafor land gjeld ikkje berre førekomsten av hiv, men også korleis smitten skjer, kven som utgjer risikogrupper, seksualåtferd i den generelle befolkninga, tendens til seksuell kontakt mellom høgrisikogrupper og andre grupper, førekomsten av andre seksuelt overførbare sjukdommar, stadiet av hivepidemien og nivået av insidens i ulike grupper. Desse faktorane er del av den såkalla epidemiologiske konteksten, og er avgjerande for kva slags førebyggande intervensjonar som vil ha effekt på epidemien og insidensen (11). Til dømes vil ein intervensjon som gir reduksjon i risikoåtferd $\mathrm{i}$ ei gruppe med låg insidens, sannsynlegvis ha liten effekt på ein generalisert hivepidemi. Det er med andre ord viktig å ha god lokal forkunnskap før ein planlegg hivførebyggjande intervensjonar. Det er sjølvsagt ikkje praktisk muleg å studere den lokale konteksten i alle lokalsamfunn, men grundige tverrfaglege studiar i område med ulik utvikling av epidemien kan vere avgjerande. Innsikt frå slike studiar kan gi betre grunnlag til å vurdere kva slags tiltak som vil ha størst effekt i ulike delar av eit land. Eit land bør nemleg ikkje berre ha éin strategi for hivførebygging. I praksis gjer dette behovet for god lokalkunnskap det nødvendig med lokal forskingskompetanse på kva som har effekt kor, mellom anna fordi lokale forskarar lettare enn utan- landske forskarar kan delta i eit kontinuerleg samarbeid med styresmaktene for å finne fram til gode førebyggjande tiltak i ulike kontekstar.

\section{Kritikk av rådande tiltaksprioritering}

Vår forskingsgruppe ved Universitetet i Bergen har lang forskingspraksis frå partnarskap med universitet i ei rekke afrikanske og asiatiske land. Vi ser behovet for ei rekke strategiske endringar i innretninga av den internasjonale bistanden. Det er lite å utsetje på retorikken, men den dekker ofte over faktiske prioriteringar - og handling. Prioriteringa av effektiv primærførebygging er eit godt eksempel her: førebygging blir prioritert ned så snart behandling er tilgjen- er avgjerande for nedkjemping av fattigdom og for å betra helsen generelt $(17,18)$. Dette er også blitt posisjonen til Verdsbanken; «Higher education is likely the only course that will lead to sustained development [...] and partnerships in capacity building could be an effective way to accelerate the pace towards excellence» (17). Men Afrika sakkar stadig lenger etter på området høgare utdanning og eiga forsking. Medan $70 \%$ av ungdommen i den rike delen av verda har tilgang til høgare utdanning, er tilsvarande tal $6 \%$ i Afrika. Noreg var tidleg ute med eit program for styrking av kompetanse ved partnaruniversitet i Afrika og Asia gjennom forskingssamarbeid med norske universitet, i form av Nasjonalt program for utvikling,

\section{«Det er med andre ord viktig å ha god lokal forkunnskap før ein planlegg hivførebyggjande intervensjonar»}

geleg. Redaktøren i The Lancet, Richard

Horton, uttrykker dette på ein dekkande måte i ein leiar: «It may be right that WHO calls the finding that nearly 3 million people are now receiving antiretroviral therapy a remarkable achievement. But it is surely scandalous that this access to medicines campaign has not been matched by an access to prevention campaigns» (12). Historia gjentar seg. Forsking har avslørt ei rekke tapte arenaer for effektiv førebygging $(13,14)$.

Desintegrering eller vertikalisering av program utgjer ei stor hindring for kostnadseffektive tiltak. Eit eksempel her er det omfattande programmet for å førebygge hivsmitte frå mor til barn. Programmet isolerer si innretting til førebygging av den vertikale smitten og utnytter ikkje det store førebyggjande potensialet programmet kunne hatt knytt til smitterisikoen til foreldra. Sentrale aktørar har innsett dette og har eksempelvis føreslått at ein i Afrika integrerer tiltak knytt til tusenårsmåla 4, 5 og 6, dvs. knytt til barnehelse, reproduktiv helse og hiv. Det er også eit behov for studiar av synergieffektar av slike integrerte tiltak. Problemet med manglande integrering heng truleg saman med eit enno meir omfattande og alvorleg problem: avgrensa lokalt eigarskap. Mylderet av donorar ynskjer ofte ulik innretning der den største bilaterale donoren, USA, stiller i eigen klasse ved å etablere eigne mål og strategiar (15). Igjen ser vi at praksis ikkje samsvarar med retorikken om lokalt eigarskap som er sentral i Paris-deklarasjonen til OECD av 2005 (16).

Det er eit stort paradoks at verdssamfunnet ikkje er villig til å investere i lokal kompetanse. Styrking av høgare utdanning og lokal forskingskompetanse er avgjerande, ikkje berre for effektive hiv/aids-program, men forsking viser også at høgare utdanning forskning og utdanning (NUFU) som blei etablert i 1988. Dette programmet har fătt svært god evaluering, og kopling til andre finansieringskjelder (kvoteprogrammet, Norads program for masterstudier (NOMA), Forskingsrådet, EU) har gitt omfattande synergieffektar både når det gjeld lokal kompetansebygging og forsking. Det har derfor vore eit stort paradoks at midlane til dette programmet har blitt meir enn halvert sidan etableringa.

\section{Bistandspolitiske element}

Vi etterlyser ei langt meir kritisk norsk bistandspolitisk røyst og større grad av langsiktig tenking. Grad av suksess når det gjeld styrking av lokalt eigarskap og effektiv førebygging heng nært saman med suksess på området lokal kompetansebygging. Her bør Noreg gå i spissen for ei internasjonal solidaritetsrørsle ved å investere i utdanning, særleg høgare utdanning og forsking. Ei slik satsing vil ha ei generell bistandspolitisk grunngjeving. Institusjonsbygging gjennom Sør-Nord-partnarskap er her ein effektiv strategi, og der utgjer forskingssamarbeid ein kritisk viktig komponent.

\section{Knut Fylkesnes (f. 1945)}

er professor ved Senter for internasjonal helse, Universitetet i Bergen. Han har doktorgrad frå Universitetet i Troms $\varnothing$ på helse- og sjukdomsåtferd, og dei siste 20 år har hans forskingsfokus vore innan hivepidemiologi og førebyg-

ging av hiv i Afrika og Asia.

Ingen oppgitte interessekonflikter.

\section{Marte Jürgensen (f. 1977)}

er utdannet lege. Hun jobber som stipendiat ved Senter for internasjonal helse, ved Universitetet i Bergen.

Ingen oppgitte interessekonflikter. 
Ingvild Fossgard Sandøy (f. 1977)

er lege og forsker, med doktorgrad frå Universitetet i Bergen, innen hivepidemiologi.

Ingen oppgitte interessekonflikter.

\section{Litteratur}

1. Global report: UNAIDS report on the global AIDS epidemic 2010. Genève: UNAIDS, 2010.

2. Orroth KK Freeman EE, Bakker R et al. Understanding the differences between contrasting HIV epidemics in east and west Africa: results from a simulation model of the Four Cities Study. Sex Transm Infect 2007; 83 (suppl 1): i5-16.

3. Michelo C, Sandøy IF, Fylkesnes K. Marked HIV prevalence declines in higher educated young people: evidence from population-based surveys (1995-2003) in Zambia. AIDS 2006; 20: 1031-8.

4. Hargreaves JR, Bonell CP, Boler T et al. Systematic review exploring time trends in the association between educational attainment and risk of HIV infection in sub-Saharan Africa. AIDS 2008; 22 403-14

5. Sandøy IF, Michelo C, Siziya S et al. Associations between sexual behaviour change in young people and decline in HIV prevalence in Zambia. BMC Public Health 2007; 7: 60.

6. Dzekedzeke K. Adult mortality in the era of HIV in Zambia: making plusible estimtes of adult mortality and the impact of HIV from limited data. Bergen: Senter for internasjonal helse, Universitetet i Bergen, 2008: 120.

7. Lingappa JR, Lambdin B, Bukusi EA et al. Regiona differences in prevalence of HIV-1 discordance in Africa and enrollment of HIV-1 discordant couples into an HIV-1 prevention trial. PLoS ONE 2008; 3: e1411.

8. Fylkesnes K, Musonda RM, Sichone M et al. Declining HIV prevalence and risk behaviours in Zambia: evidence from surveillance and populationbased surveys. AIDS 2001; 15: 907-16.

9. Dunkle KL, Stephenson R, Karita E et al. New heterosexually transmitted HIV infections in married or cohabiting couples in urban Zambia and Rwanda: an analysis of survey and clinical data. Lancet 2008; 371: 2183-91.

10. Chin J. The AIDS Pandemic the collision of epidemiology with political correctness. Bd. 1. Oxon, UK: Radcliffe Publishing, 2007.

11. Grassly NC, Garnett GP, Schwartländer B et al. The effectiveness of HIV prevention and the epidemiological context. Bull World Health Organ 2001; 79: $1121-32$.

12. Horton R, Das P. Putting prevention at the forefront of HIV/AIDS. Lancet 2008; 372: 421-2.

13. Sandøy IF. Siziya S, Fylkesnes K. Lost opportunities in HIV prevention: programmes miss places where exposures are highest. BMC Public Health 2008; 8: 31 .

14. Njeru MK, Blystad A, Shayo EH et al. Practicing provider-initiated HIV testing in high prevalence settings: consent concerns and missed preventive opportunities. BMC Health Serv Res 2011; 11: 87.

15. Hellevik SB. Making the money work: challenges towards coordination of HIV/AIDS programmes in Africa. I: MacLean SJ, Brown SA, Fourie P, red. Health for some. The political economy of global health governance. Basingstoke: Palgrave Macmillan Houndsmill, 2009.

16. Wohlgemuth L. Can Africa make use of the new aid architecture? Afr Dev 2008; 33: 31-41.

17. Materu P. Accelerating catch-up: tertiary education for growth and competitiveness in sub-Saharan Africa. Accra: Verdensbanken, 2009.

18. Ahmad K, Bloom D. Higher education in developing countries: peril and promise. Washington, D.C.: Verdensbanken 2000

Mottatt 27.6. 2011, første revisjon innsendt 22.7. 2011, godkjent 4.8. 2011. Medisinsk redaktør Erlend Hem. 